\title{
Effectiveness of Adolescent Reproductive Health Promotion Models About Puberty in Young Adolescents
}

\author{
$1^{\text {st }}$ Noor Azizah \\ Midwifery Study Program \\ Muhammadiyah University of Kudus \\ Kudus, Indonesia \\ noorazizah@umkudus.ac.id
}

\author{
$2^{\text {nd }}$ Dewi Noor Wakhidah \\ Midwifery Study Program \\ Muhammadiyah University of Kudus \\ Kudus, Indonesia \\ dewinoor@umkudus.ac.id
}

\author{
$3^{\text {rd }}$ Sokhiyatun \\ Midwifery Study Program \\ Muhammadiyah University of Kudus \\ Kudus, Indonesia \\ sokhiyatun@umkudus.ac.id
}

\begin{abstract}
One of the characteristics of female puberty is menstruation. First menstruation is usually experienced by women around the age of 10 years but can be faster or slower. The first menstruation for girls will cause problems, namely someone who faces feeling the first menstruation feeling fear and anxiety. The purpose of this study was to determine the effect of the effectiveness of adolescent reproductive health promotion models about puberty with the small group discussion method to increase knowledge and attitudes toward puberty in young girls. This research is a quasi-experiment with a pre-test and post-test design approach with a total of 46 people. The results of the study showed there were differences in scores in the control group and the intervention group namely $p<0.05$. The Small Group Discussion Method provides an opportunity for young girls to share their experiences and knowledge about puberty.
\end{abstract}

\section{Keywords-Adolescent Reproductive, Health Promotion}

\section{INTRODUCTION}

Very rapid growth during puberty occurs in 1-2 years and sexual maturity lasts six months to the next year. The rapid growth of female puberty occurs at the age of 8.5-11.5 years with a peak maturity of an average age of 12.5 years. Growth period decreases at the age of 17-18 years. As for men, the growth is rapid between the ages of $10.5-14.5$ years with a peak maturity of $14.5-15.5$ years. The period of growth decreases when the age of 21 years [1].

One psychological aspect of physical changes during puberty is that adolescents pay close attention to their bodies and build their own image of how their bodies are. Gender differences mark teenagers' perceptions of their bodies. Adolescent girls are less satisfied with their body condition and have a more negative body image, compared to before puberty [2].

Health promotion is a process of community empowerment that is an effort to increase awareness, willingness and ability in the health sector. Health promotion in schools involves all relevant parties, namely students, parents, community leaders and community organizations. Education in schools provides positive student behavior towards health developing life skills that support physical, mental and social health [3].

Group methods in health promotion there are didactic methods that require extensive knowledge, the skills to give lectures and the ability to answer questions clearly. The essential method requires sensitivity and understanding of group processes. An experimental method is used when the behavioral goals are interests, attitudes, obstacles and trust. The discussion method is considered superior compared to the lecture method for a homogeneous audience and has the same goal. Caused by the feeling of the same identity, as a group that experiences the same problem the same risk [4].

The small group discussion model is a learning process by carrying out small group discussions with the aim that students have the skills to solve problems related to the subject matter and problems encountered in daily life. The results of the interview students said that they were ashamed to ask about menstruation, there were fear and shame to speak, information was obtained from lessons and the teacher, asking parents there were some students who did not dare to ask about the physical changes they experienced.

\section{REVIEW OF LITERATURE}

Health-promoting behaviors (HPB) are defined as a positive approach to living, increasing well-being, and self-actualization. Health promoting activities are defined as those activities that contribute to health, while preventive behaviors are actions to avoid or forestall the development of disease. Pender described a healthy lifestyle as incorporating the complementary components of both health promotion and prevention. HPB develop the energy necessary to increase human potential. Use of HPB complements the stabilizing tendency of disease prevention, which is directed toward early detection. Rather than stabilization and avoidance of disease, HPB develop the tension necessary to increase human potential. [9].

Most girls obtained information about menstruation and/or puberty from their mothers [11]. Menarche at the age of 12 years old [12]. an effect of reproduction health counseling on the readiness in coping menarche among female students of Junior High School [13]

\section{METHODS}

This research is an analytical observational research with cross sectional design. The population of this study was all of the 46 female teenagers. Data collection by questionnaire. The sampling technique used in this study is total sampling. The control group was 23 people and the intervention group was 23 people. In the intervention group 23 teenagers in Small Group Discussion 4-5 people.

IV. FINDINGS AND DISCUSSION

TABLE 1. KNOWLEDGE OF PUBERTY

\begin{tabular}{|c|c|c|c|c|}
\hline \multirow[b]{2}{*}{ Knowledge } & \multicolumn{2}{|c|}{ Control Group } & \multicolumn{2}{|c|}{ Intervention Group } \\
\hline & Pre & Post & Pre & Post \\
\hline \multirow[t]{2}{*}{ Good } & 12 & 16 & 11 & 19 \\
\hline & $52.2 \%$ & $69.6 \%$ & $47.8 \%$ & $82.6 \%$ \\
\hline \multirow[t]{2}{*}{ Enough } & 11 & 7 & 12 & 4 \\
\hline & $47.8 \%$ & $30.4 \%$ & $52.2 \%$ & $17.4 \%$ \\
\hline Total & 23 & 23 & 23 & 23 \\
\hline p-value & \multicolumn{2}{|c|}{0.248} & \multicolumn{2}{|c|}{0.005} \\
\hline
\end{tabular}


Research on knowledge about puberty in the intervention group using the small group discussion method. Each group consists of 34 young girls. The material provided is about the characteristics of puberty in women, signs of physical and psychological changes, personal hygiene during menstruation including dressing pads and pain management. In the intervention group there was an increase in good knowledge from $47.8 \%$ to $82.6 \%$. small group discussion method is effective in increasing knowledge about puberty in adolescents ( $p$ value $<0.05$ )

\section{TABLE 2 THE ATTITUDE OF ADOLESCENTS AT PUBERTY}

\begin{tabular}{ccccc}
\hline & \multicolumn{2}{c}{ Control Group } & \multicolumn{2}{c}{ Intervention Group } \\
\cline { 2 - 5 } Attitude & Pre & Post & Pre & Post \\
Good & 6 & 9 & 8 & 17 \\
& $26.1 \%$ & $39.1 \%$ & $34.8 \%$ & $73.9 \%$ \\
Enough & 17 & 14 & 15 & 6 \\
& $73.9 \%$ & $60.9 \%$ & $65.2 \%$ & $26.1 \%$ \\
\hline Total & 23 & 23 & 23 & 23 \\
\hline p-value & \multicolumn{2}{c}{0.083} & \multicolumn{3}{c}{0.013} \\
\hline
\end{tabular}

Research attitudes about puberty in the intervention group using the small group discussion method. Each group consists of 3-4 young girls. In the intervention group, there was an increase in good attitude from $34.8 \%$ to $73.9 \%$. the small group discussion method is effective in improving attitudes about puberty in adolescents $(\mathrm{p}$ value $<0.05$ )

Sources of information about menstrual hygiene to teachers as the main source (43.1\%) [5]. Lack of knowledge, culture and traditions, socioeconomic and environmental causes discomfort and stress affecting girls during menstruation. [6]. Teenagers who are trained by school health trainers have better habitual practices with hygiene practices, such as bathing during menstruation and the use of sanitary pads [7]. The intervention group was given a booklet which found that reproductive education was the most influential among knowledge, emotional responses and attitudes towards menarche [8]

Girls had inadequate knowledge about menstruation; menarche as a trigger for girls learning about menstruation was common. Adolescents struggled with menstrual hygiene. Negative emotions were associated with menarche and menstrual management. A minority of studies dealt explicitly with puberty. Most girls obtained information about menstruation and/or puberty from their mothers, although mothers were not necessarily girls [10].

social, cultural and religious beliefs and attitudes that contribute to the behavior of women who are menstruating and women. The negative impacts of practice involve including exacerbating shame and stigmatization, preventing religious activities, and increasing absenteeism from work and school [11]

\section{CONCLUSION}

There is an effect of increasing knowledge and attitudes about puberty in the intervention group by using small group discussions with $\mathrm{p}$ value $<0.05$. Small group discussions are more effective in providing information about puberty in adolescents because of exchanging information and more open sharing of experiences

\section{ACKNOWLEDGEMENT}

We thank the participants, rector of the university of muhammadiyah Kudus, the department of research and community service, and all those who have helped with this research.

\section{REFERENCES}

[1] H. Z. Pieter and N. L. Lubis, Pengantar Psikologi Untuk Kebidanan, Jakarta: PT. Fajar Interpratama Mandiri, 2013.

[2] J. W. Santrock, Adolesence Perkembangan Remaja, Jakarta: Erlangga, 2003.

[3] A. Agustini, Promosi Kesehatan, Sleman: DEEPUBLISH CV. Budi Utama, 2014

[4] O. Emilia, Y. S. Prabandari and Supriyati, Promosi Kesehatan dalam Lingkup Kesehatan Reproduksi, Yogyakarta: Gadjah Mada University Press, 2019.

[5] T. Gultie, D. Hailu and Y. Workineh, "Agr of Menarche and Knowledge about Menstrual Hygiene Management Among Adolescent School Girls in Amhara Province, Ethiopia to Health Care Workers \& School Teachers," PMC Journals, 2014.

[6] A. M. Lahme, R. Stern and D. Cooper, "Factors Impacting on Menstrual Hygiene and Their Implications for Health Promotion.," SAGE Journals, 2016.

[7] S. Djalalinia, F. R. Tehrani, H. M. Afzali, F. Hejazi and N. Peykari, "Parents or School Health Trainers, which of them is Appropriate for Menstrual Health Education?," International Journal of Preventive Medicine, pp. 622-627, 2012.

[8] Setyowati, M. Rizkia and T. Ungsianik, "Improving Female Adolescents, Knowledge, Emotional Response and Attitude toward Menarche following Implementation of Menarcheal Preparation Reproductive Health Education," Asian/Pacific Island Nursing Journal, pp. 84-91, 2019.

[9] N. J. PanJ. Pander, N., L. Mourdaugh, C., \& Ann Parsons, M. (2015). Health promotion in nursing practice. https://doi.org/10.7748/ns.5.23.37.s49der, C. L. Mourdaugh, and M. Ann Parsons, "Health promotion in nursing practice.," 2015.

[10] E. Coast, S. R. Lattof, and J. Strong, "Puberty and menstruation knowledge among young adolescents in low- and middle-income countries: a scoping review," Int. J. Public Health, vol. 64, no. 2, pp. 293-304, 2019, doi: 10.1007/s00038019-01209-0.

[11] N. A. Ganabathy, A. Widjajakusuma, and D. Hidayat, "Age Pattern at Menarche as Results from a Puberty Survey," Althea Med. J., vol. 3, no. 4, pp. 640-643, 2016, doi: 10.15850/amj.v3n4.952.

[12] A. Asni and L. H. Dwihestie, "The effect of reproductive health counseling on readiness of managing menarche," J. Heal. Technol. Assess. Midwifery, vol. 1, no. 1, pp. 35-39, 2018, doi: 10.31101/jhtam.445.

[13] Y. Mohamed et al., "A qualitative exploration of menstruation-related restrictive practices in Fiji, Solomon Islands and Papua New Guinea," PLoS One, vol. 13, no. 12, pp. 1-19, 2018, doi: 10.1371/journal.pone.0208224. 